\title{
Limitations of eDNA analysis for Carcinus maenas abundance estimations
}

\author{
Ariella M. Danziger ${ }^{1}$, Zachary H. Olson ${ }^{2}$ and Markus Frederich ${ }^{1 *}$
}

\begin{abstract}
Background: Environmental DNA (eDNA) is an effective tool for the detection and monitoring of presence or absence of rare and invasive species. These techniques have been extended to quantify biomass in vertebrates, particularly in fish species. However, the efficacy of eDNA techniques to quantify biomass in invertebrate species has rarely been examined. This study tested whether eDNA could be used to determine the biomass of the worldwide invasive green crab, Carcinus maenas. In a controlled laboratory study, the relationship between biomass and C. maenas eDNA concentration was examined in the context of different biotic (activity) and abiotic (temperature) parameters.

Results: When incubating different numbers of crabs in sterile saltwater for up to 7 days, a relationship between eDNA concentration and biomass was observed at temperatures of $6.7^{\circ} \mathrm{C}$ and $18.7^{\circ} \mathrm{C}$, but not at $12.8^{\circ} \mathrm{C}$. Additionally, motor activity, aggression level, time of sampling, and features of organismal decay had significant impact on the concentration of $C$. maenas eDNA collected.

Conclusions: We show that eDNA concentration did not correlate with biomass, and that biomass, temperature, organismal characteristics, and potentially many more parameters affect shedding and degradation rates for eDNA in this species, thus, impacting the recoverable eDNA concentration. Therefore, eDNA techniques are not likely to provide a reliable signal of biomass in the invasive invertebrate species $C$. maenas.
\end{abstract}

Keywords: Environmental DNA, Biomass, Invasive species monitoring, Green crab, Carcinus maenas

\section{Background}

Environmental DNA (eDNA) is frequently used to detect the presence or absence of species, particularly those of interest due to conservation status, rarity, or ecological importance $[1,2]$. eDNA is any DNA released by an organism, in membrane-bound forms as individual cells or organelles, or as extracellular DNA, that can be isolated from environmental samples such as water, soil, or air [1-4]. DNA is naturally released, or shed, by organisms due to movement, through excretory processes, by advection of surrounding water, or after an organism's

\footnotetext{
${ }^{*}$ Correspondence: mfrederich@une.edu

${ }^{1}$ School of Marine and Environmental Programs, University of New England, 11 Hills Beach Rd, Biddeford, ME, USA

Full list of author information is available at the end of the article
}

death due to processes of decay $[5,6]$. The use of eDNA in species survey applications is supported by the fact that eDNA degrades in the environment allowing for eDNA detections to be linked to species presence at meaningful temporal and geographic scales [4, 7-10]. However, degradations rates seem to vary greatly in freshwater and marine environments, as shown for a broad range of species, like common carp 4.2 days [8], Amphibian larvae $7-14$ days [7], sturgeon, 14 days [11], bullfrog $<1-54$ days [4], flounder 0.9 days [2], anchovy, sardines and mackerel 3-4 days [10], or stickleback 6.7 days [7].

The fate of eDNA, and therefore its detection and quantification, is affected by several factors that collectively have been referred to as the ecology of eDNA [12, 13], which accounts for the processes of organismal shedding of DNA, degradation rates of eDNA, and transport 
of eDNA within the environmental matrix. These processes are affected by hydrology (for eDNA sampling conducted in water), biology and ecology of the organism, stress levels (i.e., causing metabolic changes and thus differences in rate of release of eDNA), abiotic factors, and other biotic factors $[2,14,15]$. For example, hydrological conditions (e.g., current, wind, depth) at the site of water collections can influence transport and retention of eDNA [13, 16, 17]. The shedding and degradation rates of eDNA, as well as transport of this DNA to other locations, are affected by the biology of the organism, including its behavior, movement (both within and away from the site), individual and group characteristics, and biomass $[10,11,18]$. For example, a higher density or biomass of the species could lead to increased shedding of DNA, and thus a higher concentration of eDNA at the sampling site [10]. Lastly, the abiotic and biotic environment plays a role in all four of the factors influencing the fate of eDNA. Some examples of abiotic factors which affect eDNA include UV light, temperature, and salinity, while other biotic factors include enzyme or microbialinduced degradation $[4,16,19,20]$.

As features of the ecology of eDNA have been examined for specific systems, the utility of eDNA methods has been extended beyond presence/absence sampling to estimation of biomass or relative abundance of species, with most such efforts focusing on vertebrates [15, 21-24]. Some early eDNA studies connected species biomass with amplification rates, where higher rates of DNA amplification from species-specific assays were correlated with higher species abundances at the sample sites [e.g., 25, 26]. Quantification of eDNA from samples led to successful correlations of eDNA concentrations with species biomass, for example in laboratory studies of the common carp, Cyprinus carpio [22] and brook char, Salvelinus fontinalis [23]. However, variation in those factors affecting the ecology of eDNA in field settings have been shown to add complexity to the relationship between species abundance or biomass and eDNA concentrations [22, 23].

One promising application of eDNA methods is the detection of invasive species [27-29]. Whereas most such studies have focused on vertebrates, the use of eDNA methods has been attempted on invertebrate species, especially in more recent years (Orconectes rustic and Pacifastacus leniusculus) [30, 31]. The European green crab, Carcinus maenas, is an invasive invertebrate that has spread world-wide, caused damage to coastal environments, reduced marine species richness through outcompeting and consuming native species [32,33], and destroyed eelgrass beds while feeding [34]. This destruction leads to a loss of protective habitat for a multitude of species, particularly during larval or juvenile stages [34,
35]. In the nineteenth century, C. maenas was introduced to the northern Atlantic Coast of the USA, and has since spread and invaded South Africa, Japan, Pacific Coast of USA, Canada, Tasmania, and Argentina [36-38] and is expected to invade Antarctica [39]. Its adaptability to new environments and competition with native organisms makes it imperative to create a reliable way to track this species' global spread to allow for faster eradication of the species in new areas. The presence or absence of $C$. maenas has been determined using eDNA analysis in the Gulf of Maine [40], but it is unclear whether this tool can be used to determine the community biomass of C. maenas. Therefore, the goal of this study is to test whether the biomass of $C$. maenas correlates to the concentration of $C$. maenas eDNA in a controlled lab environment, and furthermore to test how specific features of the ecology of eDNA, abiotic and other biotic factors, alter the correlation between $C$. maenas eDNA concentrations and biomass. For $C$. maenas in particular, determining the biomass or population size in a particular area could help to adjust the methods of eradication of the species, while also determining if eradication is possible due to species abundance. Furthermore, estimating the abundance of this species could aid in predictions of changes in native populations, and thus methods of conservation of these other organisms.

\section{Results \\ Correlation of biomass and temperature to eDNA concentration}

The correlation between crab biomass $(1,3$, or 6 crabs per bucket; $1.48 \mathrm{~g} / \mathrm{L}, 4.3 \mathrm{~g} / \mathrm{L}$ or $8.2 \mathrm{~g} / \mathrm{L}$ ) and crab eDNA concentration (measured by qPCR) was inconsistent. At a density of 6 crabs, eDNA concentrations differed significantly among temperature treatments (ART: $\left.\mathrm{F}_{4,352}=11.05, \mathrm{p}=1.9 \mathrm{E}-08\right)$. At $7{ }^{\circ} \mathrm{C}$ and $18{ }^{\circ} \mathrm{C}$ the largest biomass $(8.2 \mathrm{~g} / \mathrm{L})$ consistently showed the highest eDNA concentration (Tukey-Test: $\mathrm{p}<0.05$ ). The lowest biomass revealed at multiple, but not all, timepoints the lowest eDNA concentration (Fig. 1). At $13{ }^{\circ} \mathrm{C}$, however, no significant differences in eDNA from the separate crab densities were found (Tukey-Test: $p>0.05$ ). eDNA degradation after removal of the crabs from the buckets also varied with temperature. At $6.7{ }^{\circ} \mathrm{C}$ and $12.8^{\circ} \mathrm{C}$ eDNA concentrations remained relatively constant. However, at $17.8{ }^{\circ} \mathrm{C}$ the eDNA concentration quickly decreased, presumably due to DNA degradation (ART: $\mathrm{F}_{18,352}=3.32$, $\mathrm{p}=1.4 \mathrm{E}-08)$.

\section{Behavior}

\section{Activity}

After 10 min of running on an underwater treadmill at about $60 \%$ of their maximum speed, the active crabs 


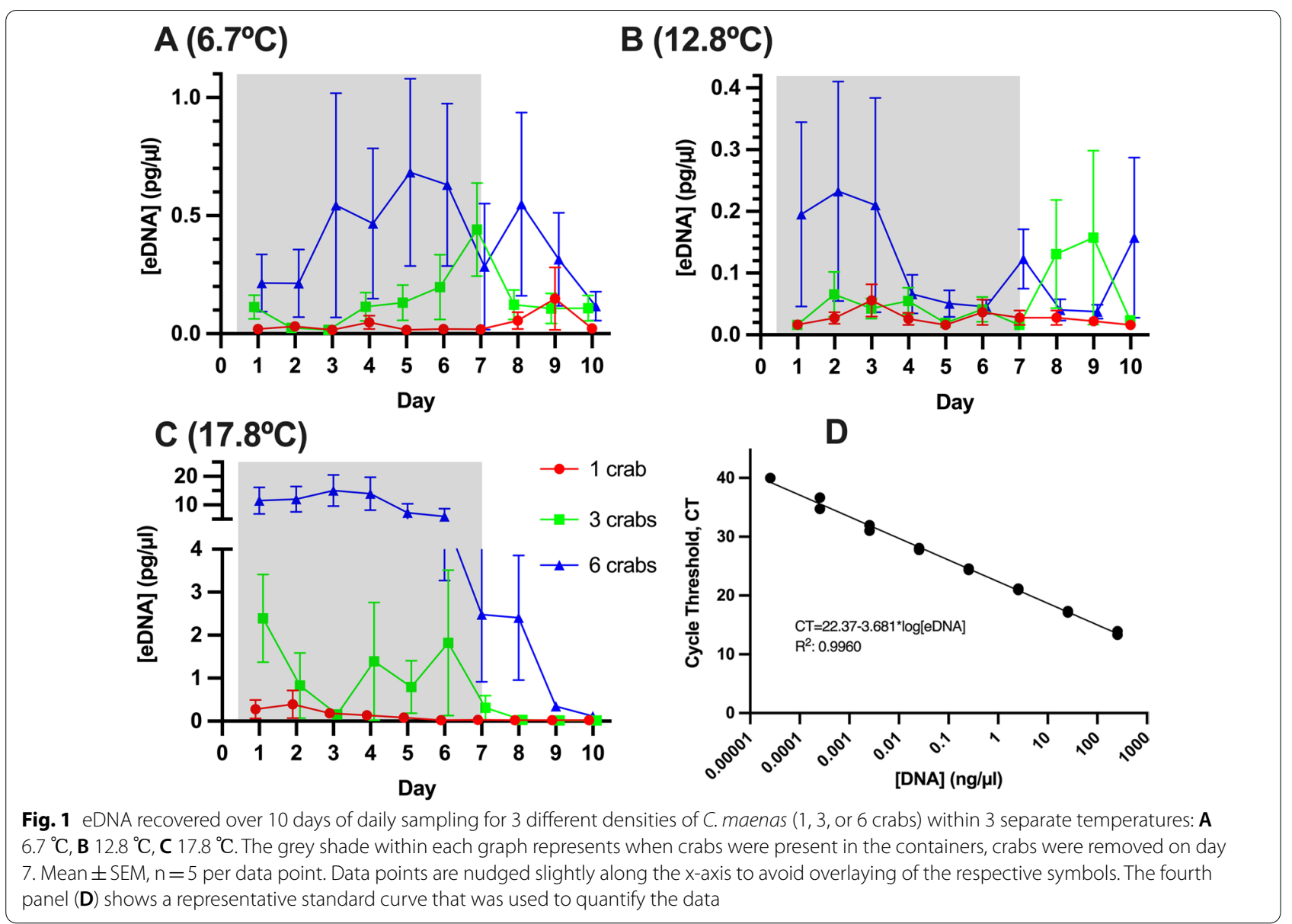

released a significantly higher amount eDNA compared to the stationary crabs, which were immobile on the treadmill (ART: $\mathrm{F}_{1,24}=16.75, \mathrm{p}=4.17 \mathrm{E}-4$; Fig. 2). Stationary crab eDNA was not different from control values $(p>0.05)$. After $10 \mathrm{~min}$ of running and a resting period of $10 \mathrm{~min}$ (time point $20 \mathrm{~min}$ ), eDNA concentration in the active condition decreased to low concentrations no different from that of the stationary crab $(0.0199 \pm 0.014 \mathrm{vs}$. $0.0278 \pm 0.023 \mathrm{pg} / \mu \mathrm{l}$, respectively; $\mathrm{p}>0.05$ ).

\section{Aggression}

Crabs with different aggression levels exuded variable amounts of eDNA over time (Fig. 3). Consistently, however, aggression level 1 crabs (low aggression) released significantly more eDNA than the crabs of aggression level 2, 3, or that of the mixed aggression groups (ART: $\left.\mathrm{F}_{4,112}=12.7, \mathrm{p}=1.5 \mathrm{E}-08\right)$.

\section{Organismal decay}

Lower amounts of solution from decaying (homogenized) crabs yielded a higher eDNA concentration $\left(\mathrm{F}_{4,51}=6.9\right.$, $\mathrm{p}=1.5 \mathrm{E}-05$ ) (Fig. 4). Furthermore, time of sampling had

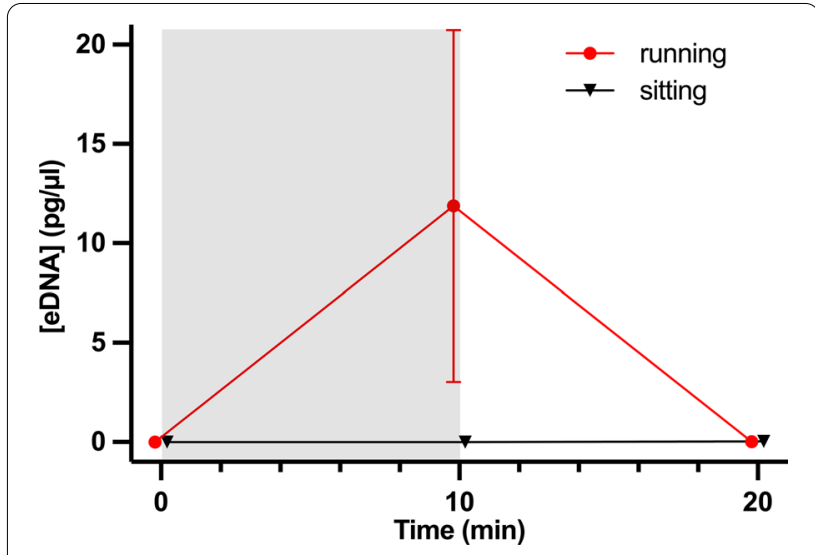

Fig. 2 eDNA recovered from crabs walking on an underwater treadmill for $10 \mathrm{~min}$ and subsequent rest of $10 \mathrm{~min}$, compared to 20 min rest only. Active running on the motor-driven belt by the active crab is represented by the grey shade. Mean $\pm S E M, n=5$ per data point. Data points are nudged slightly along the $x$-axis to avoid overlaying of the respective symbols 


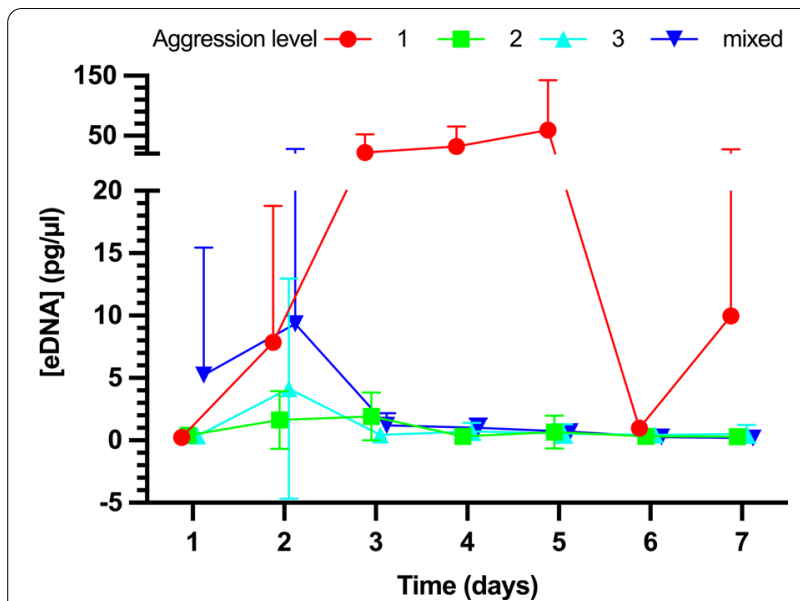

Fig. 3 eDNA release over seven consecutive days for 3 separate aggression levels of $C$. maenas, and all 3 combined levels of aggression (mixed). Mean \pm SEM, error bars are shown in only one direction for some data points for clarity of the figure, $n=5$ per data point. Data points are nudged slightly along the $x$-axis to avoid overlaying of the respective symbols

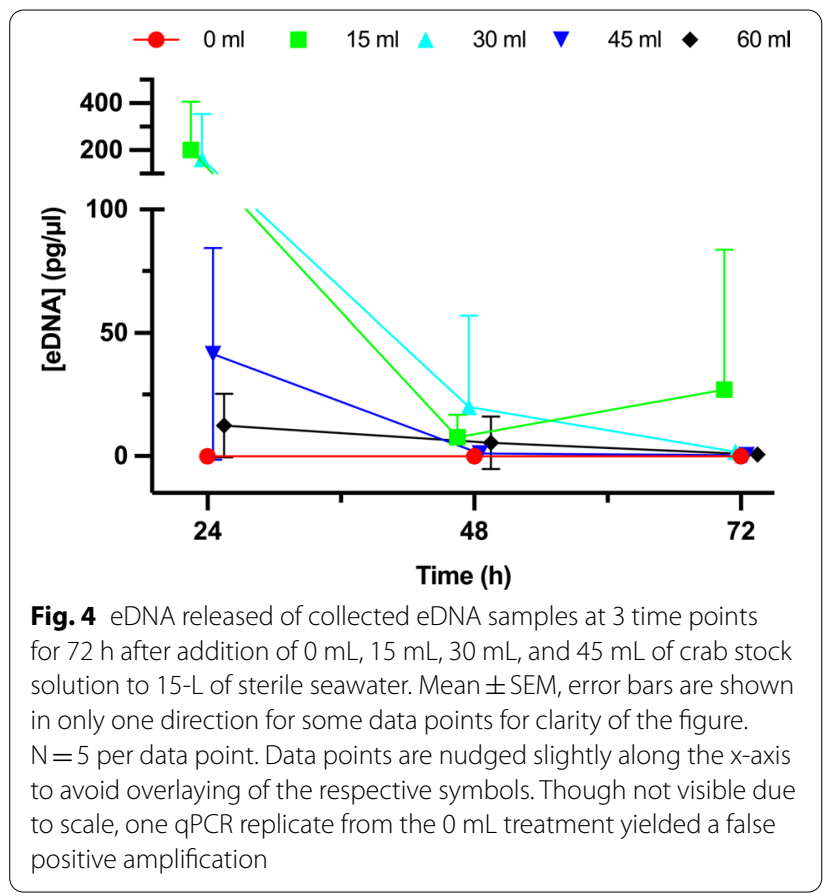

a significant effect on eDNA concentration; after $24 \mathrm{~h}$, the amount of eDNA collected significantly decreased (ART: $\mathrm{F}_{2,51}=13.8, \mathrm{p}=1.6 \mathrm{E}-05$ ).

\section{eDNA recovery}

The percentage of [eDNA] recovery continuously decreased over a 72-h period and exhibited a negative linear relationship with time $(y=-0.001255 x+0.101783$, $\left.R^{2}=0.996, p=0.0225\right)$ (Fig. 5).

\section{Water filtration}

A linear relationship $\left(y=-0.0107 x+38.2829, R^{2}=0.95\right.$, $\mathrm{p}=0.0225)$ existed between 100 and $600 \mathrm{ml}$ filtered water and the respective recovered eDNA concentration (Fig. 6). Volumes of $100 \mathrm{ml}$ were close to the detection limit, volumes of $400 \mathrm{~mL}$ and larger easily clogged the filters. As a result, the smallest volume of water we could filter and continuously get DNA amplification with was $200 \mathrm{ml}$. All water was subsequently sampled and filtered as $200 \mathrm{ml}$.

\section{Contamination}

The control buckets held for all experiments with only sterile artificially made seawater consistently had no amplification of DNA.

\section{Discussion}

The first part of our study examined the relationship between $C$. maenas eDNA concentration and $C$. maenas density (1,3, and 6 crabs), and how this relationship is impacted by seawater temperatures $\left(6.7^{\circ} \mathrm{C}, 12.8^{\circ} \mathrm{C}\right.$, and $17.8^{\circ} \mathrm{C}$ ), the range of which was chosen to reflect changes in the yearly average water temperature observed in the Gulf of Maine [41, 42]. Our results demonstrate that eDNA concentration cannot consistently be related to biomass of $C$. maenas. While a density of 6 crabs produced eDNA concentrations that were different from those of 1 and $3 \mathrm{crab}$ treatments, this difference was only observed at two temperatures $\left(6.7^{\circ} \mathrm{C}\right.$ and $\left.17.8{ }^{\circ} \mathrm{C}\right)$. Work by Lacoursiére-Roussel et al. [22] on brook char at two different temperatures $\left(7{ }^{\circ} \mathrm{C}\right.$ and $\left.14{ }^{\circ} \mathrm{C}\right)$ revealed that shedding rates scale proportionally with temperature, where an increase in temperature led to a higher shedding rate of eDNA. This could be due to changes in mobility and the metabolic rate of organisms at higher temperatures $[9,18,22,43]$. Our study shows that eDNA analysis cannot be used to rigorously predict biomass of C. maenas in a controlled lab experiment and suggests against eDNA methods for that purpose in the field.

Multiple factors, aside from temperature, could influence the relationship (or lack thereof) between C. maenas biomass and eDNA concentration. General shedding rates of eDNA depend on a multitude of factors including temperature, stress, diet, biomass, life stage, and individual organismal characteristics $[4,10,18,22,43]$.

First, we tested motor activity for its effect on C. maenas eDNA release. As expected, increased crab activity triggered greater release of eDNA compared to immobile crabs. The rapid decrease of an eDNA signal just $10 \mathrm{~min}$ after ending the walking activity was very surprising, but 


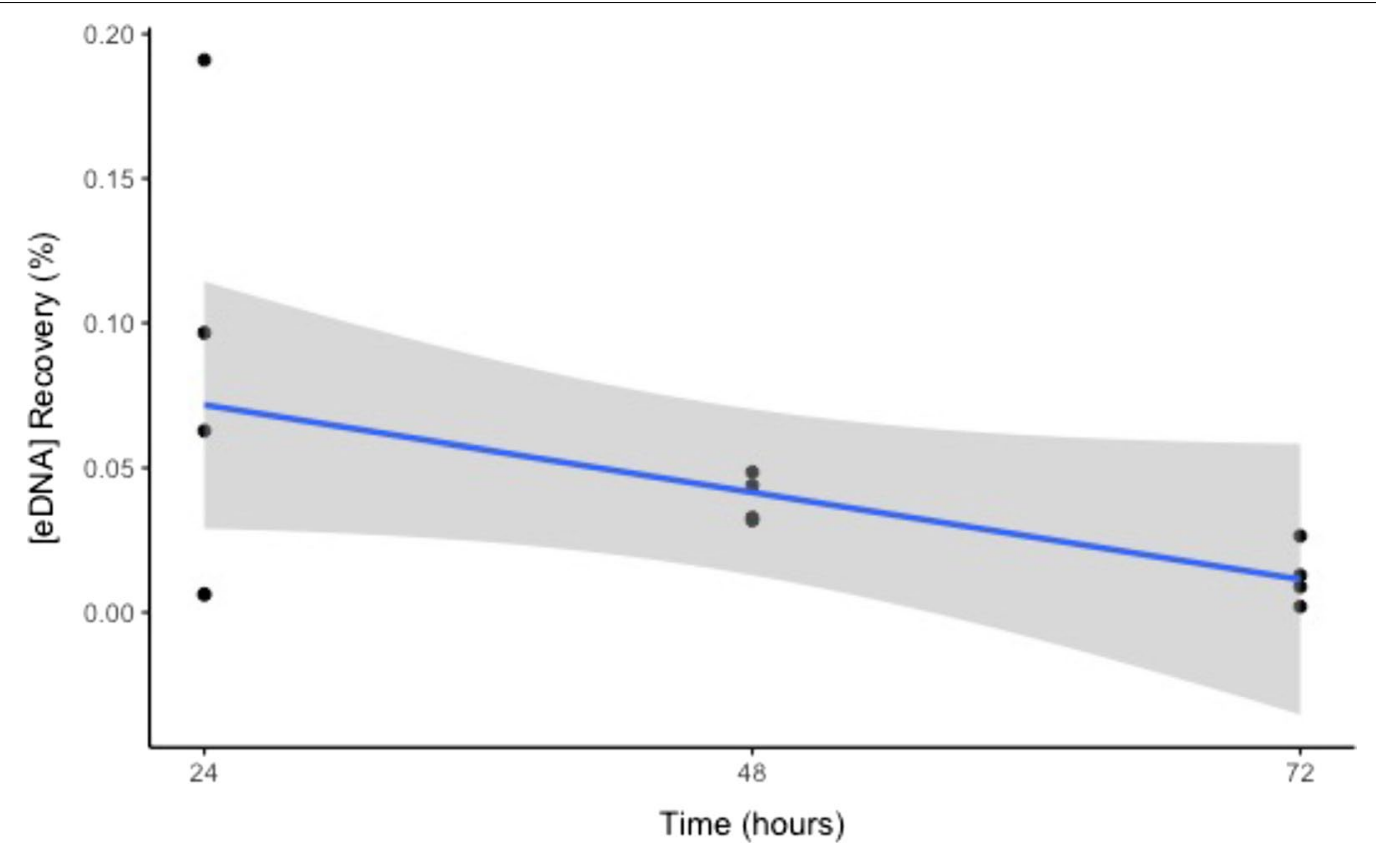

Fig. 5 [eDNA] recovery percentage over three time points within $72 \mathrm{~h}$. The solid line represents the regression line $\left(R^{2}=0.996\right)$, and the grey shaded area represents the standard error of the regression line

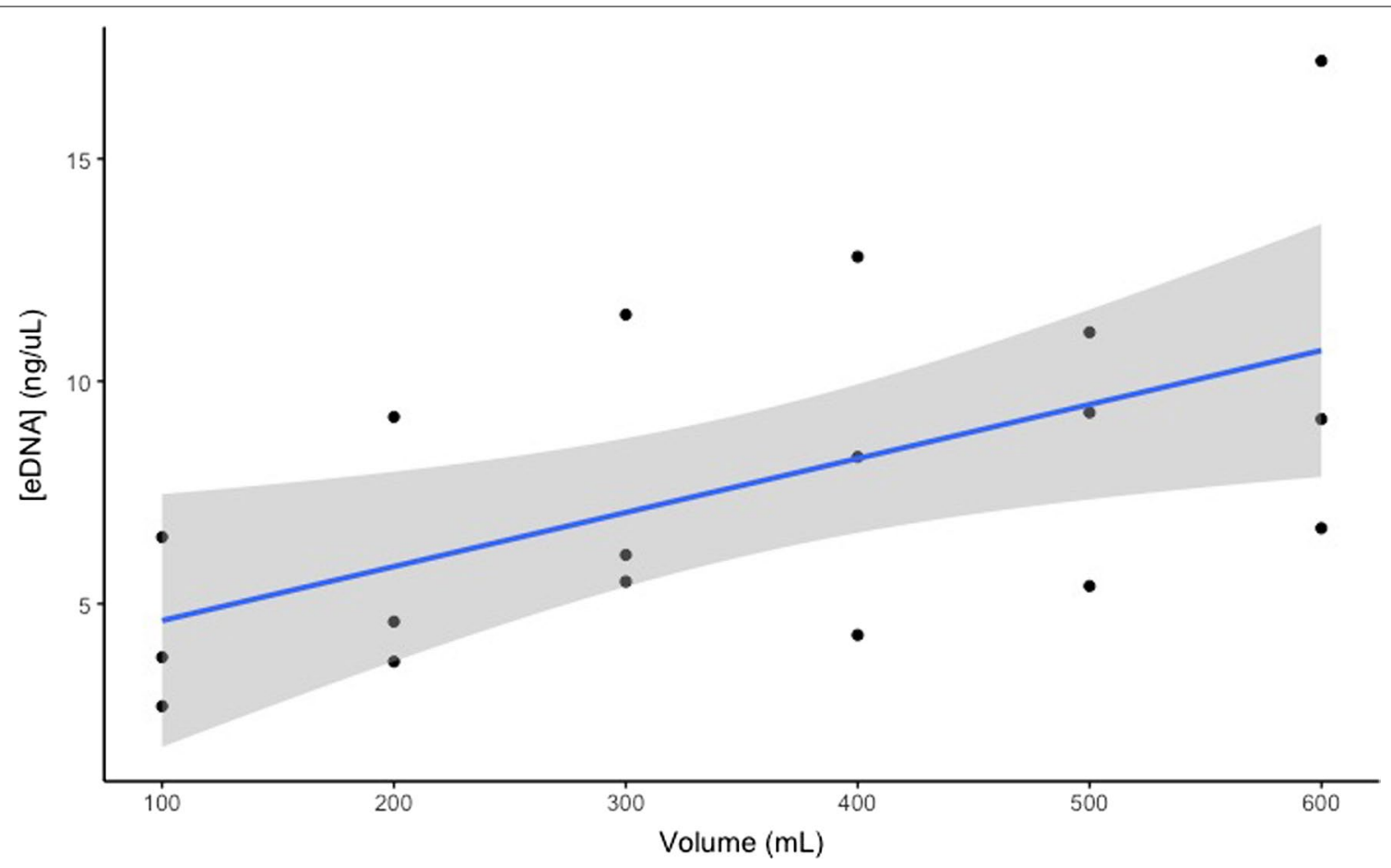

Fig. 6 DNA concentration from six volumes of filtered water from 100 to $600 \mathrm{~mL}$. The solid line represents the linear regression line $\left(R^{2}=0.95\right)$ and the grey shaded area represents the standard error of the regression line 
highly reproducible in the experiment. Further tests will need to investigate why the eDNA signal disappeared that rapidly but persisted much longer in the other bucket experiments. We tested the effect of motor activity on eDNA release only at one temperature $\left(7.8{ }^{\circ} \mathrm{C}\right)$, but it is likely that temperature-induced activity levels contribute to increased eDNA release rates at increasing temperatures. As an ectotherm, responding to temperature changes with a metabolic rate following a $Q_{10}$ of $2-3$, C. maenas increases its activity at higher water temperatures [44]. In a separate experiment, we found that at $17.8{ }^{\circ} \mathrm{C}$, active crabs released significantly more eDNA compared to active crabs in the two lower temperature treatments. Thus, it can be expected that crabs at this higher temperature released more eDNA at least partially due to increased, temperature-induced activity, as suspected in the experiment listed above.

In the same context, we also investigated the effect of aggression level on eDNA release. We predicted that high aggression crabs would release the most eDNA but found that the lowest aggression crabs released the most eDNA. Reasons for these unexpected results have not been investigated further. However, future studies should determine if activity level amongst aggression levels differs. For example, if level 1 (low aggression) crabs avoid higher level aggression crabs by evasion, and higherlevel aggression crabs stand their ground, level 1 crabs would have more motor activity and therefore released more eDNA. Besides testing eDNA released between aggression levels, scenarios in which all aggression levels of crabs were mixed together were also tested. The amount of eDNA detected was similar to that of medium and high aggression. Furthermore, eDNA levels seemed to oscillate over time in all aggression groups. It is possible that overall activity levels varied over time, leading to variation in eDNA release. The consistency and reproducibility of this oscillating eDNA release suggests a specific process is involved. However, identifying this process was not possible without monitoring or controlling for the voluntary motor activity of the crabs over time, which was not a focus of the current study. Nevertheless, our results suggest that aggression levels impact the amount of eDNA being released in an environment. Notably, aggression levels do vary among populations. Recent results show that in a subsample of more than 300 crabs C. maenas from Maine, 58\% were aggression level 1, $42 \%$ were level 2, and $0 \%$ were aggression level 3, while crabs from Nova Scotia were 30\% level 1,50\% level 2 , and 20\% level 3 aggression [45]. Given these findings, if eDNA correlations to biomass were made, it would be necessary to take into account not only the seawater temperature and motor activity, but also the percentage of each aggression level within the population in question.
eDNA is not only released from live animals, but also from dead ones, including those that were fed on by predators or conspecifics and therefore potentially released large amounts of eDNA [3]. If more crabs are present one can expect more mortalities, thereby impacting the amount of eDNA in the water column. Our simulations of organismal decay (i.e., by adding different amounts of homogenized crab to water), produced unexpected results: samples with smaller volumes of homogenized crab resulted in higher recoverable eDNA concentrations than did higher volume treatments. These results might be explained by larger volumes of homogenized crabs also containing more nucleases and other DNA degrading enzymes, potentially leading to greater DNA degradation or PCR inhibition $[8,46]$. Such results clearly demonstrate that the simple notion or prediction of more crab biomass (in this case dead) leading to more eDNA is not consistent or correct.

The three factors that we found affecting eDNA concentrations were activity level, temperature, and biomass (at $6.7{ }^{\circ} \mathrm{C}$ and $17.8{ }^{\circ} \mathrm{C}$ ). Activity level specifically has not previously been studied for its impact on eDNA concentration. However, while working with juvenile and adult bluegill sunfish, Lepomis macrochirus, Maruyama et al. [18] found that juveniles released higher amounts of eDNA, possibly due to their higher activity and metabolic rate. Similarly, our study demonstrated that eDNA concentration increased with higher motor activity of C. maenas. Furthermore, Crane et al. [47] found that larval stage affects eDNA release in $C$. maenas. While their study focused on eDNA from sediment samples, the study concluded that ovigerous organisms shed more DNA than those in other life stages, though eDNA concentration and detection was still low [47].

Temperature can delay or accelerate DNA degradation. Colder temperatures have been shown to delay degradation, while warmer water temperatures speed degradation [4]; eDNA degradation rates at $5{ }^{\circ} \mathrm{C}$ are much slower compared to those at $20^{\circ} \mathrm{C}$ or higher $[4,9,16]$. The increased degradation rate at higher temperatures is due to several factors. Increased microbial and enzymatic activity in warmer temperatures can stimulate DNA degradation [20,48, 49]. Lower temperatures also slow microbial DNA decay, thus aiding to the slowed overall eDNA degradation rate $[9,50]$. Our experiments show that with higher temperatures, more eDNA is released, however degradation also appears to occur faster in both our experiment and the published data.

Multiple studies in fish species have shown that biomass is positively correlated with eDNA concentration. Klymus et al. [15] found a linear relationship between eDNA concentration and fish biomass for both bighead carp and silver carp. A similar study by Takahara 
et al. [23] confirmed this linear relationship in common carp. By contrast, others have found no relationship between species' abundance and eDNA concentration in Cryptobranchus alleganiensis (hellbender salamander) [51], Triturus cristatus (northern crested newt) [52], Orconectes rusticus (rusty crayfish) [30, 31], Pacifcastacus leniusculus (American signal crayfish) [31]. The differences in relationships between eDNA and species biomass could be due to the multitude of confounding variables, such as those which affect shedding and degradation rates, timing of sampling throughout the life cycle or breeding season, and many more [51]. The findings of our study align with those examining other crustaceans [30, 31]. For C. maenas, while eDNA concentration does increase with biomass at some temperatures, biomass determinations could not be consistently made using this technique.

The effect of organismal decay on eDNA release and detection has scarcely been studied. Our data show that as the amount of decomposing organismal matter increases, the eDNA detected decreases. Possible inhibition of PCR due to enzymatic activity released during decay was investigated, and no inhibition of primers was occurring. Such findings are similar to examinations by Curtis and Larson [53] of invasive red swamp crayfish (Procambarus clarkia). In a swamp enclosure, the carcasses of this crayfish released no detectable eDNA into the water column. Similar to our study, inhibition of primers was tested for, and no inhibition was found. Thus, this study suggested that carcasses may not release a detectable amount of eDNA, suggesting that live organisms contribute most, if not all, eDNA detected.

Time of sampling was the last factor analyzed within this study. As time since release of eDNA into the water column increases, the amount of eDNA degradation increases, however this rate of degradation can vary between species and amount of eDNA released $[4,16]$. For this reason, time of sampling and the subsequent eDNA detected was analyzed using C. maenas. Our results were congruent with previous data, i.e., that of the eDNA detection of the Idaho giant salamander, showing that time of sampling after introduction and removal of a species to a water source adjusts the amount of eDNA detected. After the introduction to a new location, the collected eDNA of the Idaho giant salamander (Dicamptodon aterrimus) exhibited an initial high release of eDNA. After removal of the species, eDNA concentrations found in the water samples began to degrade and was undetectable after 3 days with $D$. aterrimus [16]. Similar to our study with C. maenas, DNA quickly began to degrade, however detection after 3 days depended on the temperature of the water.

\section{Conclusions}

Overall, our study shows that various abiotic and biotic parameters alter the concentration of $C$. maenas eDNA in the water, via increasing or decreasing shedding and degradation rates. If individual parameters affecting eDNA concentration could be separated, a clear correlation between eDNA concentration and the respective parameter might be possible. Our conceptual model (Fig. 7) illustrates potential correlations between parameters investigated in this study and those reported in the literature with at least two competing trends in two different directions. For determining biomass of a population of animals in the water at different temperatures, depths, and directions of flow, where the animals show different activity levels, aggression levels, life stages, feeding status, and many other not controlled conditions (for example, we did not measure $\mathrm{pH}$ levels throughout our incubations and $\mathrm{pH}$ can have an effect on eDNA release and recovery; [4] and citations therein), the resulting eDNA concentration is merely a sum of all these effects. In the case of $C$. maenas, a high eDNA concentration could be generated by a few highly active crabs present at the time of the water sampling, which are feasting on several dead crabs. By contrast, the same high eDNA concentration might have come from many inactive crabs having left the area some time ago, but an initially higher eDNA level produced by these inactive crabs had decreased by degradation. A multitude of scenarios are possible, and the current biotic and abiotic scenario present at the time of eDNA sampling is generally unknown. Therefore, a determination of biomass of $C$. maenas, and potentially of many other species, is likely to be inaccurate when using eDNA. Our study, along with previous findings $[30,31]$ demonstrate that more studies should be conducted to determine exactly which species' biomass sizes can be determined using eDNA quantification.

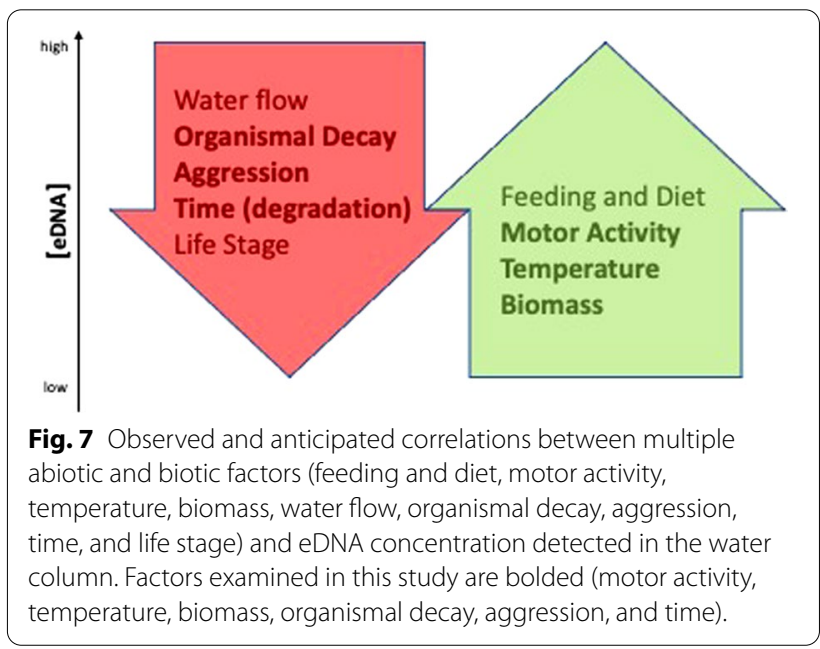




\section{Methods}

\section{Experimental design}

Crabs for this study were collected by hand in the rocky intertidal zone on the oceanic side of Biddeford Pool, Maine $\left(43.442292{ }^{\circ} \mathrm{N}, 70.341244{ }^{\circ} \mathrm{W}\right)$ and kept in a 500 -L tank in a sea water flow-through system in the Marine Science Center of the University of New England. Additional male $C$. maenas were hand collected and trapped in Kejimkujik Seaside National Park, Nova Scotia, Canada $\left(43.50323^{\circ} \mathrm{N} 64.50041^{\circ} \mathrm{W}\right)$. These were transported in coolers by car to the Marine Science Center of the University of New England in Biddeford, Maine, where they were held in separate $300 \mathrm{~L}$ tanks with a flow through sea water system. Water discharged from the system was filtered through $1 \mu \mathrm{m}$ filters and sterilized using 2 UV filters (QL-40 Lifegard Ultraviolet Sterilizer) before release into the local river. As a secondary containment, all of this was housed in a 4-m diameter pool. The setup was permitted and inspected by the Maine Department of Marine Resources (permit numbers S2013-007, S2014-007, S2015-008, S2016-008, S2017-007). Animals were fed frozen fish and squid ad libitum. Institutional Animal Care and Use Committee approval is not required for experiments involving invertebrates.

In a controlled lab experiment we incubated different numbers of green crabs (C. maenas) under different conditions (biomass, motor activity, organismal activity, aggression level, temperature, and eDNA degradation; details are outlined below). For all laboratory experiments, artificial seawater (Instant Ocean SeaSalt with deionized water, $32 \mathrm{ppt}$ ) was used to avoid DNA contamination from other sources. Water was stored in a $120-\mathrm{L}$ container enclosed in a wooden box to aid in the exclusion of further DNA contamination. Furthermore, water was treated with UV light for $10 \mathrm{~min}$ before use to ensure sterilization of water.

Fifteen liters of artificial sea water were placed in sterile 19-L buckets containing bleached bubble stones connected to an air pump. A lid over this bucket minimized the DNA contamination from the laboratory. These 19-L containers were used for the different treatments described below. As a negative control, a bucket with only sterile sea water was continuously tested for eDNA in parallel to all experiments.

\section{Correlation of biomass and temperature to eDNA concentration}

Crabs were selected based on size and weight. Weight, carapace width, sex, and abdominal color were recorded for each crab. Crabs were grouped into densities of 1 , 3 , or 6 per bucket, equating to $22.2 \pm 3.0,64.4 \pm 3.8$, and $123.4 \pm 9.1 \mathrm{~g}$ respectively. Density groupings were kept at $6.7{ }^{\circ} \mathrm{C}, 12.8{ }^{\circ} \mathrm{C}$, or $17.8{ }^{\circ} \mathrm{C}$ for 7 days. Temperatures were chosen to correspond to seasonal water temperatures in the Gulf of Maine. Every $24 \mathrm{~h}, 200 \mathrm{~mL}$ of water was collected from each bucket and filtered as described below. The removed water was not replaced with new water to keep the potential for contaminations minimal, therefore the overall volume of water decreased slightly throughout the incubations. To minimize this decrease in water we determined the minimum amount of filtered water that provides reproducible data $(200 \mathrm{~mL})$, see Sections "Water filtration" for details. After 7 days, crabs were removed from the buckets and water was sampled daily for an additional 3 days to measure degradation rates. All treatments (densities of $C$. maenas within various temperatures) and sample collections were replicated 5 times.

\section{Behavior \\ Motor activity}

We compared eDNA release between when C. maenas were resting and running on an underwater treadmill. The treadmill consisted of an acrylic aquarium and a motorized belt $(30 \times 20 \mathrm{~cm})$ and perforated box $(20 \times 19 \times 14 \mathrm{~cm} ; \mathrm{L} \times \mathrm{W} \times \mathrm{H})$ to keep the crabs centered on the treadmill [54]. Before use, the treadmill was sterilized with $10 \%$ bleach and rinsed with deionized water. It was then filled with 15 -L sterile artificial seawater, and $200 \mathrm{~mL}$ of this water was collected for filtration. Crabs ran on the belt for $10 \mathrm{~min}$ at a speed of $20 \mathrm{~cm} / \mathrm{s}$ (about $60 \%$ of their maximum running speed, as determined prior to the experiments), and then rested for $10 \mathrm{~min}$. Water was agitated and samples were taken after $10 \mathrm{~min}$ running and $10 \mathrm{~min}$ resting. Size-matched crabs rested on the belt for $20 \mathrm{~min}$ as controls with the same water collection time points. All water samples were filtered immediately. The treadmill was sterilized between each trial. We tested 10 crabs in total, 5 running, 5 at rest, thus taking 5 replicates of each treatment in this experiment.

\section{Aggression}

Aggression levels of green crabs were ranked from 1 (least aggressive) to 3 (most aggressive). When agitated with a probe touching their face crabs with a level 1 aggression kept their claws close to their body and ran away. Level 2 aggression crabs opened their claws into a meral spread and held their stance. Level 3 aggression crabs attacked the probe and other nearby crabs immediately.

Crabs were chosen haphazardly, and their aggression levels determined. Crabs from the Gulf of Maine had level 1 or 2 (low or medium) aggressions only. Therefore, 
we also used crabs from Nova Scotia, which showed consistently higher aggression levels (2 or 3) [55]. Crabs were paired in 19-L buckets as follows: 3 crabs level 1, 3 crabs level 2, 2 crabs level 3 (level 3 crabs from Nova Scotia were larger; to maintain similar biomass, only 2 were used), and 2 crabs level 1 with 2 crabs level 2 and 1 crab level 3. The total biomass per bucket for aggressions 1,2 , and 3 was $112.9 \pm 9.9 \mathrm{~g}$, the mixed aggression bucket was $224.3 \pm 8.3$ g. Every $24 \mathrm{~h}$ for one week $200 \mathrm{~mL}$ of water were collected from each bucket. Water collected was immediately filtered. Five trials of this experiment were completed.

\section{Organismal decay}

To simulate organismal decay, 4 crabs (biomass average of $32 \mathrm{~g}$ ) were crushed and then homogenized with $400 \mathrm{~mL}$ water using a blender to create a stock solution. This solution was mixed into buckets with $15-\mathrm{L}$ of sterile sea water in four volumes: $15,30,45$, and $60 \mathrm{~mL}(\mathrm{n}=5$ replicate buckets per volume of stock solution). Water collection for filtration occurred every $24 \mathrm{~h}$ for 3 days. $200 \mathrm{~mL}$ of water was immediately filtered after collection. After qPCR analysis, it was found that samples expected to have high eDNA concentrations in fact showed the opposite trend. Thus, we tested to ensure PCR inhibition did not occur. We spiked a sample of DNA isolated from the crab homogenate with DNA isolated from crab hepatopancreas. Comparing the respective PCR results of DNA from the hepatopancreas alone, from the crab homogenate, and the crab homogenate spiked with DNA from the hepatopancreas showed predicted DNA concentrations and therefore no PCR inhibition by the crab homogenate.

\section{eDNA recovery}

DNA from the hepatopancreas of C. maenas was isolated using the Qiagen DNeasy Blood and Tissue Kit following the protocol for DNA isolations from tissue. The concentration of this DNA was quantified using a NanoDrop ${ }^{\text {TM }}$ 2000 Spectrophotometer. $50 \mu \mathrm{L}$ of $255 \mathrm{ng} / \mu \mathrm{L}$ DNA was added to 15 - $\mathrm{L}$ of sterile seawater ( $\mathrm{n}=5$ replicates). $200 \mathrm{~mL}$ of water was filtered every $24 \mathrm{~h}$ for three days. Percent recovery was determined using the total genomic DNA concentration as the starting point of our recovery.

\section{Water filtration}

A water filtration system with four $300 \mathrm{~mL}$ filtration funnels and sterile $0.45 \mu \mathrm{m}$ cellulose nitrate filters (Sartorius, Germany; \#11,306-47-ACN) connected to a vacuum pump (Gast DOA-P7004-AA) was constructed (see Additional file 1: Fig. S1). In a lightproof box a 7 W UV light was used to sterilize the filtration setup for $10 \mathrm{~min}$ before each water filtration. After water samples were filtered, filters were stored in individual sterile $2 \mathrm{~mL}$ Eppendorf tubes at $-80{ }^{\circ} \mathrm{C}$ until DNA isolation.

For determinations on the minimum volume of water that could be collected and filtered to test for the presence of eDNA from C. maenas, water was sampled from a $500 \mathrm{~L}$ tank containing more than 100 green crabs in six volumes $(100,200,300,400,500$, and $600 \mathrm{~mL}, \mathrm{n}=3$ per volume). This water was filtered and eDNA was isolated using the Qiagen DNeasy Blood and Tissue Kit. DNA was amplified using the designed primers and TaqMan probe sequence for $\mathrm{qPCR}$, and total DNA concentration was measured using a ThermoFisher NanoDrop ${ }^{\mathrm{TM}}$ spectrophotometer.

\section{DNA isolation and quantitative PCR}

The Qiagen DNeasy Blood and Tissue Kit was used to isolate DNA from filters following the manufacturer's instructions with minor modifications. $180 \mu \mathrm{L}$ of buffer ATL and $20 \mu \mathrm{L}$ proteinase $\mathrm{K}$ were added to the filter and incubated at $56{ }^{\circ} \mathrm{C}$ for $10 \mathrm{~min} .200 \mu \mathrm{L}$ of buffer $\mathrm{AL}$ was then added to the samples and incubated for another $10 \mathrm{~min}$ at $56{ }^{\circ} \mathrm{C}$. After all incubations, $200 \mu \mathrm{L}$ of ethanol was added and samples were centrifuged for $1 \mathrm{~min}$ at $8000 \mathrm{rpm}$ to aid in the separation of the liquid from the filter. The liquid was pipetted into a DNeasy Mini Spin column and centrifuged once more for $1 \mathrm{~min}$ at $8000 \mathrm{rpm}$. The column was washed with $500 \mu \mathrm{L}$ buffer AW1 and $500 \mu \mathrm{L}$ of buffer AW2. $200 \mu \mathrm{L}$ of buffer AE was used to elute the DNA from the spin column and eluted DNA was stored in $-80{ }^{\circ} \mathrm{C}$.

Quantitative real-time PCR (qPCR) was performed on isolated DNA samples in duplicates with primers and TaqMan probe sequences specific to C. maenas in the Gulf of Maine [40]. Sequences were forward primer 5'AAT ATT GGG AGG GCC AGA TAT AG-3', reverse primer 5'-AGG ATC GAA GAA TGA GGT GTT TAG3', TaqMan probe 5'- 6-FAM-GGT TCT GAT TAC TTC CTC CGT CTT TAA CCT-MGB -3'. qPCR conditions were $15 \mathrm{~min}$ at $95{ }^{\circ} \mathrm{C}$; then 40 cycles of $15 \mathrm{~s}$ at $95{ }^{\circ} \mathrm{C}$ and $1 \mathrm{~min}$ at $62{ }^{\circ} \mathrm{C}$. The last segment was one cycle for $1 \mathrm{~min}$ at $95{ }^{\circ} \mathrm{C}, 30 \mathrm{~s}$ at $62{ }^{\circ} \mathrm{C}$, and $30 \mathrm{~s}$ at $95{ }^{\circ} \mathrm{C}$. For every qPCR run, two positive and negative (blank) controls were run along with the collected samples. Samples with a cycle threshold (CT) below 40 were considered positive amplification. Samples that did not reach the CT after 40 cycles were considered negative, and we used the value of 0 (zero) to calculate the respective average concentrations.

To quantify the DNA concentration with qPCR, DNA was isolated from the hepatopancreas of $C$. maenas using the Qiagen DNeasy Blood and Tissue Kit and the 
concentration was determined using a NanoDrop $^{\mathrm{TM}} 2000$ Spectrophotometer. A standard curve of CT and a dilution series of eDNA concentrations between 255 and $2.55 \times 10^{-5} \mathrm{ng} / \mu \mathrm{l}$ was created (Fig. 1D) and used quantification. The $\mathrm{R}^{2}$ for this standard curve was 0.996 , the slope of -3.681 represents an efficiency of $82.7 \%$

\section{Statistics}

For all experiments, one or two-way type III ANOVAs were used to test for the effects of each variable on the cycle threshold (CT) or eDNA concentration. Oneway ANOVAs were used for water eDNA recovery and water filtration; two-way ANOVAs were used for biomass and temperature, activity, aggression, and organismal decay. P-values less than 0.05 were considered significant. Assumptions of normality and heteroscedasticity were checked with Shapiro-Wilks and Levene tests, respectively. For experiments with only one variable (motor activity and eDNA recovery) Kruskal-Wallis tests were performed. Data with more than one variable were analyzed with the Aligned Rank Transform (ART) if assumptions for ANOVA were not met [56]. If the statistical test was significant, we used post-hoc Tukey tests to differentiate significant treatments. Data are shown as means \pm 1 SEM.

\section{Abbreviations}

CT: Cycle Threshold; eDNA: Environmental DNA; qPCR: Quantitative real-time polymerase chain reaction.

\section{Supplementary Information}

The online version contains supplementary material available at https://doi. org/10.1186/s12862-022-01969-z.

Additional file 1: Figure S1. Photo of the filtration setup. Four filter funnels are housed in a light proof plywood box that allows for UV sterilization prior to filtration. 2 water traps collect the water and protect the vacuum pump.

\section{Acknowledgements}

This study was supported through grants from the National Science Foundation, NSF, Grant\# IUSE 1431955 and EPSCoR 1849227 to M.F.

\section{Authors' contributions}

The study was designed by AMD and MF. AMD performed most of the experiments and wrote the first draft of the manuscript. Data analysis and manuscript completion was done by AMD, MF, and ZHO. All authors read and approved the final manuscript.

\section{Funding}

National Science Foundation, NSF, Grant\# IUSE 1431955 and EPSCoR 1849227.

\section{Availability of data and materials}

The datasets generated during and/or analyzed during the current study are available from the corresponding author on request.

\section{Declarations}

Ethics approval and consent to participate

All experiments were carried out following approved standard procedures for working with invertebrate animals.

\section{Consent for publication}

Not applicable.

\section{Competing interests}

The authors have no relevant financial or non-financial interests to disclose.

\section{Author details}

${ }^{1}$ School of Marine and Environmental Programs, University of New England, 11 Hills Beach Rd, Biddeford, ME, USA. ${ }^{2}$ University of New England, School of Social and Behavioral Sciences, Animal Behavior Program, 11 Hills Beach Rd, Biddeford, ME, USA.

Received: 16 August 2021 Accepted: 24 January 2022

Published online: 07 February 2022

References

1. Taberlet P, Coissac E, Hajibabaei M, Rieseberg LH. Environmental DNA. Molec Ecol. 2012;21(8):1789-93.

2. Thomsen PF, Willerslev E. Environmental DNA — an emerging tool in conservation for monitoring past and present biodiversity. Biol Conserv. 2015;183:4-18.

3. Deiner K, Altermatt F. Transport distance of invertebrate environmental DNA in a natural river. PLoS ONE. 2014;9(2):e88786.

4. Strickler KM, Fremier AK, Goldberg CS. Quantifying effects of UV-B, temperature, and $\mathrm{pH}$ on eDNA degradation in aquatic microcosms. Biol Conserv. 2015;183:85-92.

5. Foote AD, Thomsen PF, Sveegaard S, Wahlberg M, Kielgast J, Salling AB, Galatius A, Orlando L, Gilbert MTP. Investigating the potential use of environmental DNA (eDNA) for genetic monitoring of marine mammals. PLOS ONE. 2012;7(8):e41781.

6. Thomsen PF, Kielgast J, Iversen LL, Møller PR, Rasmussen M. Detection of a diverse marine fish fauna using environmental DNA from seawater samples. PLoS ONE. 2012;7(8):41732.

7. Thomsen PF, Kielgast J, Iversen LL, Wiuf C, Rasmussen M, Gilbert MTP, Orlando L, Willerslev E. Monitoring endangered freshwater biodiversity using environmental DNA. Mol Ecol. 2012;21:2565-73.

8. Barnes $M A$, Turner $C R$, Jerde $C L$, Renshaw MA, Chadderton $W L$, Lodge DM. Environmental conditions influence eDNA persistence in aquatic systems. Env Sci Technol. 2014;48(3):1819-27.

9. Eichmiller JJ, Best SE, Sorensen PW. Effects of temperature and trophic state on degradation of environmental DNA in lake water. Env Sci Technol. 2016:50:1859-67.

10. Sassoubre LM, Yamahara KM, Gardner LD, Block BA, Boehm AB. Quantification of environmental DNA (eDNA) shedding and decay rates for three marine fish. Env Sci Technol. 2016;50:10456-64.

11. Dejean T, Valentini A, Duparc A, Pellier-Cuit S, Pompanon F, Taberlet P, Miaud C. Persistence of environmental DNA in freshwater ecosystems. PLoS ONE. 2011;6(8):e23398.

12. Barnes MA, Turner CR. The ecology of environmental DNA and implications for conservation genetics. Conserv Genetics. 2016;17(1):1-17.

13. Harrison JB, Sunday JM, Rogers SM. Predicting the fate of eDNA in the environment and implications for studying biodiversity. Proc Royal Soc B Biol Sci. 2019:286:20191409.

14. Goldberg CS, Pilliod DS, Arkle RS, Waits LP. Molecular detection of vertebrates in stream water: a demonstration using Rocky Mountain tailed frogs and Idaho giant salamanders. PLoS ONE. 2011;6:e22746.

15. Klymus KE, Richter CA, Chapman DC, Paukert C. Quantification of eDNA shedding rates from invasive bighead carp Hypophthalmichthys nobilis and silver carp Hypophthalmichthys molitrix. Biol Conserv. 2015;183:77-84. 
16. Pilliod DS, Goldberg CS, Arkle RS, Waits LP. Factors influencing detection of eDNA from a stream-dwelling amphibian. Molec Ecol Res. 2014;14(1):109-16.

17. Song JW, Small MJ, Casman EA. Making sense of the noise: the effect of hydrology on silver carp eDNA detection in the Chicago area waterway system. Sci Total Env. 2017;605-606:713-20.

18. Maruyama A, Nakamura K, Yamanaka H, Kondoh M, Minamoto T. The release rate of environmental DNA from juvenile and adult fish. PLoS ONE. 2014:9(12):e114639.

19. Turner CR, Barnes MA, Xu CCY, Jones SE, Jerde CL, Lodge DM. Particle size distribution and optimal capture of aqueous macrobial eDNA. Methods Ecol Evol. 2014;5(7):676-84.

20. Zhu B. Degradation of plasmid and plant DNA in water microcosms monitored by natural transformation and real-time polymerase chain reaction (PCR). Water Res. 2006;40:3231-8.

21. Doi H, Inui R, Akamatsu Y, Kanno K, Yamanaka H, Takahara T, Minamoto T. Environmental DNA analysis for estimating the abundance and biomass of stream fish. Freshwater Biol. 2017;62(1):30-9.

22. Lacoursière-Roussel A, Rosabal M, Bernatchez L. Estimating fish abundance and biomass from eDNA concentrations: variability among capture methods and environmental conditions. Molec Ecol Resources. 2016;16(6):1401-14.

23. Takahara T, Minamoto T, Yamanaka H, Doi H, Kawabata Z. Estimation of fish biomass using environmental DNA. PLoS ONE. 2012;7(4):e35868.

24. Wu Q, Kawano K, Uehara Y, Okuda N, Hongo M, Tsuji S, Yamanaka T, Minamoto T. Environmental DNA reveals nonmigratory individuals of Palaemon paucidens overwintering in Lake Biwa shallow waters. Freshwater Sci. 2018;37(2):307-14.

25. Ficetola GF, Miaud C, Pompanon F, Taberlet P. Species detection using environmental DNA from water samples. Biol Lett. 2008;4(4):423-5.

26. Olson ZH, Briggler JT, Williams RN. An eDNA approach to detect eastern hellbenders (Cryptobranchus a. alleganiensis) using samples of water. Wildlife Res. 2012;39(7):629-36.

27. Gherardi F, Aquiloni L, Diéguez-Uribeondo J, Tricarico E. Managing invasive crayfish: is there a hope? Aquat Sci. 2011;73:185-200.

28. Hinlo R, Furlan E, Suitor L, Gleeson D. Environmental DNA monitoring and management of invasive fish: comparison of eDNA and fyke netting. Manage Biol Invasions. 2017:8(1):89-100.

29. Tréguier A, Paillisson JM, Dejean T, Valentini A, Schlaepfer MA, Roussel JM. Environmental DNA surveillance for invertebrate species: advantages and technical limitations to detect invasive crayfish Procambarus clarkii in freshwater ponds. J Appl Ecol. 2014;51(4):871-9.

30. Dougherty MM, Larson ER, Renshaw MA, Gantz CA, Egan SP, Erickson DM, Lodge DM. Environmental DNA (eDNA) detects the invasive rusty crayfish Orconectes rusticus at low abundances. J Appl Ecol. 2016;53(3):722-32.

31. Larson ER, Renshaw MA, Gantz CA, Umek J, Chandra S, Lodge DM, Egan SP. Environmental DNA (eDNA) detects the invasive crayfishes Orconectes rusticus and Pacifastacus leniusculus in large lakes of North America. Hydrobiologia. 2017;800(1):173-85.

32. Griffen BD, Riley ME. Potential impacts of invasive crabs on one life history strategy of native rock crabs in the Gulf of Maine. Biol Invasions. 2015;17(9):2533-44.

33. Tan EBP, Beal BF. Interactions between the invasive European green crab, Carcinus maenas (L.), and juveniles of the soft-shell clam, Mya arenaria $\mathrm{L}$., in eastern Maine, USA. J Exp Mar Biol Ecol. 2015;462:62-73.

34. Neckles HA. Loss of Eelgrass in Casco Bay, Maine, linked to green crab disturbance. Northeast Nat. 2015;22(3):478-500.

35. Orth RJ, Carruthers TJB, Dennison WC, Duarte CM, Fourqurean JW, Heck KL, Hughes HR, Kendrick GA, Kenworthy WJ, Olyarnik S, Short FT, Waycott $\mathrm{M}$, Williams SL. A global crisis for seagrass ecosystems. Bioscience. 2006;56(12):987-96.

36. Carlton JT, Cohen AN. Episodic global dispersal in shallow water marine organisms: the case history of the European shore crabs Carcinus maenas and C. aestuarii. J Biogeogr. 2003;30:1809-20

37. Hidalgo FJ, Barón PJ, Orensanz JM. A prediction come true: the green crab invades the Patagonian coast. Biol Invasions. 2005;7:547-52.

38. Roman J. Diluting the founder effect: cryptic invasions expand a marine invader's range. Proc Royal Soc B: Biol Sci. 2006;273:2453-9.

39. Aronson RB, Frederich M, Price R, Thatje S. Prospects for the return of shell-crushing crabs to Antarctica. J Biogeogr. 2015;42(1):1-7.
40. Danziger AM, Frederich M. Challenges in eDNA detection of the invasive European green crab, Carcinus maenas. Biol Invasions. 2022 (in press).

41. Mountain DG. Labrador slope water entering the Gulf of Maine-response to the North Atlantic Oscillation. Continent Shelf Res. 2012;47:150-5.

42. Torre MP, Tanaka KR, Chen Y. A spatiotemporal evaluation of Atlantic Sea Scallop Placopecten magellanicus habitat in the Gulf of Maine using a bioclimate envelope model. Mar Coast Fish. 2018;10:224-35.

43. Gillooly JF, Brown JH, West GB, Savage VM, Charnov EL. Effects of size and temperature on metabolic rate. Science. 2001;293(5538):2248-51.

44. Rayner G, McGaw IJ. Effects of the invasive green crab (Carcinus maenas) on American lobster (Homarus americanus): Food acquisition and trapping behaviour. J Sea Res. 2019;144:95-104.

45. Botta W. Why are crabs so crabby? Possible role of biogenic amines in aggression in the European green crab Carcinus maenas. Master's Thesis, University of New England, 2020; pp. 52.

46. Saito T, Doi H. Environmental DNA degradation simulation from water temperature and DNA fragment length: a meta-analysis approach. Frontiers Ecol Evol. 2021;9:623831.

47. Crane LC, Goldstein JS, Thomas DW, Rexroth KS, Watts AW. Effects of life stage on eDNA detection of the invasive European green crab (Carcinus maenas) in estuarine systems. Ecol Indicators. 2021;124:107412.

48. Lindahl T. Instability and decay of the primary structure of DNA. Nature. 1993;363(6422):709-15.

49. Smith Cl, Chamberlain AT, Riley MS, Cooper A, Stringer CB, Collins MJ. Neanderthal DNA: not just old but old and cold? Nature. 2001;10:771-2.

50. Okabe S, Shimazu Y. Persistence of host-specific Bacteroides-Prevotella 165 rRNA genetic markers in environmental waters: effects of temperature and salinity. Appl Microbiol Biotechnol. 2007;76:935-44.

51. Spear SF, Groves JD, Williams LA, Waits LP. Using environmental DNA methods to improve detectability in a hellbender (Cryptobranchus alleganiensis) monitoring program. Biol Conserv. 2015;183:38-45.

52. Biggs J, Ewald N, Valentini A, Gaboriaud C, Dejean T, Griffiths RA, Foster J, Wilkinson JW, Arnell A, Brotherton P, Williams P, Dunn F. Using eDNA to develop a national citizen science-based monitoring programme for the great crested newt (Triturus cristatus). Biol Conserv. 2015;183:19-28.

53. Curtis AN, Larson ER. No evidence that crayfish carcasses produce detectable environmental DNA (eDNA) in a stream enclosure experiment. Peer J. 2020;8:e9333.

54. Pennoyer KE, Himes AR, Frederich M. Effects of sex and color phase on ion regulation in the invasive European green crab, Carcinus maenas. Marine Biol. 2016;163(6):1-15.

55. Logan L. One crab to rule them all: a comparison between Carcinus maenas populations with stress physiology behavior and habitat destruction. Master's Thesis, University of New England, 2018; pp. 83.

56. Wobbrock JO, Findlater L, Gergle D, Higgins JJ. The Aligned Rank Transform for nonparametric factorial analyses using only ANOVA procedures. Proceedings of the ACM Conference on Human Factors in Computing Systems (CHI '11). Vancouver, British Columbia (May 7-12, 2011). New York: ACM Press, 2001; pp. 143-146.

\section{Publisher's Note}

Springer Nature remains neutral with regard to jurisdictional claims in published maps and institutional affiliations. 